Notre Dame Law School

NDLScholarship

Journal Articles

Publications

1985

\title{
The Supreme Court and the Constitution: The Continuing Debate on Judicial Review
}

Donald P. Kommers

Notre Dame Law School, donald.p.kommers.1@nd.edu

Follow this and additional works at: https://scholarship.law.nd.edu/law_faculty_scholarship

Part of the Constitutional Law Commons, Judges Commons, and the Supreme Court of the United States Commons

\section{Recommended Citation}

Donald P. Kommers, The Supreme Court and the Constitution: The Continuing Debate on Judicial Review, 47 Rev. Pol. 113 (1985) (book review).

Available at: https://scholarship.law.nd.edu/law_faculty_scholarship/1393

This Book Review is brought to you for free and open access by the Publications at NDLScholarship. It has been accepted for inclusion in Journal Articles by an authorized administrator of NDLScholarship. For more information, please contact lawdr@nd.edu. 


\section{THE SUPREME COURT AND THE CONSTITUTION: THE CONTINUING DEBATE ON JUDICIAL REVIEW}

\section{Donald P. Kommers}

The three books reviewed in this essay are recent contributions to the growing literature of constitutional theory. ${ }^{*}$ They explore important questions about the role of the Supreme Court and the meaning of the Constitution. But as they illustrate, constitutional theory means different things to different scholars. Michael Perry offers us a theory of judicial review. His work, like John Agresto's, is animated by a fascination with what judges should do when they decide constitutional cases. It is also driven by his desire to reconcile judicial review with democracy, whereas Agresto's concern is with the relationship of judicial review to our governmental structure of separation of powers and checks and balances. Sotirios Barber, on the other hand, has a theory of the Constitution. $\mathrm{He}$ seeks to define the Constitution's meaning-its true meaning-apart from what judges and scholars say it means. What we see here, then, are differing styles of constitutional argument and varying approaches to constitutional decision-making. In the end we are brought back to one question: How is the Constitution to be interpreted and applied in modern America?

\section{Background: Judicial Review and Contemporary Constitutional Theory}

The question arises in sharp relief today because of the expansion of judicial power in the last thirty years. During this time the Supreme Court has changed the face of American society. It has required states and local governments to restructure their political systems, revise many of their social policies, and abandon laws imposing various sorts of moral constraints, especially in the area of private behavior. Most of these decisions were mandated in the name of liberty or equality, and benefitted a variety of disadvantaged groups, including welfare mothers, political dissidents, social and religious minorities, voters in certain kinds of legislative districts, inmates in prisons and mental hospitals, women seeking abortions, and even corporations wanting to spend money on political

\footnotetext{
* Michael J. Perry, The Constitution, the Courts, and Human Rights (New Haven: Yale University Press, 1982); Sotirios A. Barber, On What the Constitution Means (Baltimore and London: The Johns Hopkins University Press, 1984); and John Agresto, The Supreme Court and Constitutional Democracy (Ithaca: Cornell University Press, 1984).
} 
advertising. In defending their interests the Court has invalidated numerous state and federal laws, substituting its judgment of what the Constitution requires for policies adopted by legislative majorities.

The era of judicial activism started by the Warren Court and in important respects continued by the Burger Court has generated a new breed of Supreme Court commentators differing sharply from those of the past. The new commentators, scandalized by the racism, sexism, intolerance, and economic injustices afflicting the country, see the Supreme Court as the most readily available weapon in the battle against the inequities - and iniquities - of American life. Their Supreme Court is an activist tribunal, doing what a constitutional court, in their view, should be doing: resisting majority rule, forthrightly and unapologetically, whenever it conflicts with the fundamental rights and interests of persons living in contemporary America. The result, clearly, is the expansion of judicial power.

The older commentators - those identified with conventional constitutional analysis-have been more concerned with limiting the power of the Supreme Court. The quintessence of constitutional democracy is, in their view, majority rule. For them, accordingly, the central problem of constitutional theory is the legitimacy of judicial review. Their struggle is one of reconciling judicial review with democracy. And so they have woven a tapestry around the theme of judicial restraint. Familiar threads in their artwork are James Bradley Thayer's rule of the clear mistake, Learned Hand's moral skepticism, Alexander Bickel's passive virtues, James Wechsler's neutral principles and, most recently, John Hart Ely's representative-reinforcing theory of judicial review. The result, clearly, is the curtailment of judicial power.

The argument between the old and new commentators overlays the modern debate between the so-called "interpretivists" and "noninterpretivists," fancy terms in current usage to describe competing approaches to judicial decision-making in constitutional cases. The interpretivist holds that constitutional disputes are to be resolved-and only resolved-by reference to values found or implied in the text of the Constitution or in the intentions of the Founding Fathers. As interpretivism implies, the process here is one of constitutional interpretation. The noninterpretivist, by contrast, holds that judges may review legislation and other governmental acts by reference to values found outside of the constitutional text and original history. As noninterpretivism implies, the process here is one of constitutional policymaking.

Although the new commentators are almost all noninterpretivists, not all noninterpretivists are prepared to defend constitutional policymaking. ${ }^{*}$ For example, John Hart Ely, a noninterpretivist, writes in the older

* Some might even object to the distinction drawn earlier between constitutional policymaking and interpretation. The objection has merit. For one thing, the Founders may have authorized noninterpretive judicial review by their deliberate use of broad language such as "privileges and immunities," "due process," and "equal protection"; if such review is sanctioned by original history why not call it interpretive review? Whether a judge is making policy or interpreting the Constitution also depends on his conception of the Constitu- 
tradition of constitutional theory. Indeed, he has significantly advanced that tradition by "elaborat[ing] a normative theory of a representative political process that . . . constrain[s] judicial discretion" (Richard Davies Parker, "The Past of Constitutional Theory-And Its Future," The Ohio State Law Review, 42[198], 223). His noninterpretivism is rooted in a theory of judicial review based not on any particular provision or articulated value of the Constitution but rather on a broad inference about the nature of the polity created by the Constitution. Ely's theory-an approach advocating judicial activism when public policy flows from a serious imperfection in the process of representative government-has thus been constructed out of an unwritten constitutional principle that purportedly infuses the structures and relationships set up by the Constitution.

The new commentators, in any event, are fashioning fresh theories of the Constitution and marshaling new justifications of judicial review. They have witnessed the work product of the Warren and Burger Courts and like the Lord viewing his creation they have pronounced it good. The goal now is to spread the word, to convert the infidel, and thus to advance the good. The judges are the messengers, noninterpretivism the method. What stands in their way are the scribes and the pharisees: the formalist committed to proper procedure, the literalist concerned with the letter of the Constitution, and the legalist whose range of interpretive techniques is limited to arguments based on constitutional text, original history, and stare decisis.

The older commentators speak mainly for a morality of process. They express a utilitarian faith in the capacity of the political system, through elections and representation, to produce the greatest good for the greatest number. The function of the Supreme Court, in their reckoning, is to safeguard the democratic process and to vindicate values and rights expressly constitutionalized by the framers. The new commentators, by contrast, speak mainly for a morality of rights. The Supreme Court, for them, is a creator of rights, driven by a vision of the polity informed by moral philosophy. Some, like Ronald Dworkin, would fuse constitutional law and moral philosophy, and in this way vindicate values rooted in contemporary notions of personhood and human dignity. The antiutilitarian rights-based character of contemporary moral philosophy is, in fact, in perfect harmony with the antimajoritarian value-oriented jurisprudence of the new commentators. Personal rights are prior to general interest, and the function of the Supreme Court is to protect these rights.

Yet the interpretivist-noninterpretivist confrontation is not all that

tion. If his conception of the Constitution includes more than its text, then in truth he may be said in some general sense to be interpreting the Constitution. Or he may uphold a value that he sees embedded in the Constitution as a whole rather than any one of its parts, in which case he may be said to be extracting a value from the text, and thus interpreting it. Ely, despite his orientation to process, is usually thought of as a noninterpretivist. But he could as easily be described as an interpretivist because he bases his well-known theory of judicial review on a principle gleaned from various amendments to the Constitution. 
new. It is as old as Calder v. Bull, decided in 1798. Justice Samuel Chase was the noninterpretivist. He argued that laws could be nullified by the judiciary if they violate "the spirit of our state governments" or "general principles of law and reason." Justice James Iredell was the interpretivist: He would uphold legislation if not in conflict with the "marked and settled boundaries" of the written Constitution. These themes have been played over and over again in the history of American constitutional law. Still there is a difference between the old and the new noninterpretivism: The old sought to protect rights long recognized in law or tradition (in the nineteenth century they were called "vested rights"); the new seeks to create rights unrecognized or only dimly perceived by our forebears.

Interestingly, the debate in the academic literature does not reproduce existing divisions of opinion on the Supreme Gourt. No Supreme Court justice has ever described himself as a noninterpretivist. Under no circumstances would the justices admit that they are engaged in policymaking. They are, by self-definition, interpretivists. The public must of course believe that they are interpreting the Constitution. This is the foundation of their authority, their legitimacy. Even a justice like Thurgood Marshall, who would vindicate rights other than those fully guaranteed by the Constitution (e.g., the right to an education), nevertheless feels compelled to justify the protection of such rights in terms of their close relationship to explicitly guaranteed rights. Marshall's approach is akin to the one used by Justice William O. Douglas in Griswold v. Connecticut (1965), which upheld the right to marital privacy-a right not found in the text-because it fell within "penumbras, formed by emanations from [guaranteed rights]." Interpretivism is preserved by such verbal legerdemain.

\section{Three Regent Perspectives}

A. constitutional laW as MORal PROPHEcy

Michael Perry is a leading disciple of noninterpretivism. His goal in The Constitution, the Courts, and Human Rights is to develop "a principled argument in favor of noninterpretive review with respect to human rights issues and one that is consistent with our nation's commitment to representative democracy" (p. 24). At the outset he clears away a lot of brush blocking the view of many constitutional commentators. First, he cuts through the usual arguments against interpretivism, affirming its plausibility with respect to a number of constitutional issues. He is even in agreement with Raoul Berger's originalist criticism of the Supreme Court's interpretation of the Fourteenth Amendment (Government by Judiciary, 1977). (That is, modern equal protection jurisprudence flows neither from the constitutional text nor from original understanding.) Second, and relatedly, he uproots the notion, seeded by John Ely, that noninterpretive review can be justified by reference to the constitutional text. "Virtually all of modern constitutional decision making by the Supreme Court is almost wholly a function," he notes, "not of constitutional interpretation, but of constitutional policymaking" (p. 2). Finally, he shreds the labored and worn-out arguments so often heard in support 
of the democratic character of judicial review.* Noninterpretive review, he argues, is countermajoritarian and thus constitutes "the central problem of contemporary constitutional theory" (p. 10). The field now cleared, the author prepares us for a new harvest: a functional theory of noninterpretivism.

The overture to Professor Perry's theory is his general discussion of interpretive review and its relationship to the constitutional text. He concedes the plausibility of interpretive review, particularly with respect to judicial review of federal action under certain enumerated powers. But, in the end, original history is unimportant for him. Why? Because judicial review performs an "indispensable function" in the American system of government. The framers "plainly did intend" to establish the Constitution as supreme law, argues Perry, and he concludes that judicial review "best serves the function of fulfilling that intention." The argument turns on what Perry regards as the special institutional capacities of the Supreme Court, chief among which are its impartiality and ability to "stir the polity's sense of moral responsibility" (p. 19).

The point of all this is that if what we could plausibly regard as interpretive review is in need, ultimately, of a functional justification then certainly noninterpretive review is in need of a similar justification. It must be functional since contrary to process-oriented theorists like Ely and rights-based theorists like Dworkin "there is no plausible textual or historical justification for noninterpretive review" (p. 92) with respect to human rights. Yet the "resolution of human rights issues is," according to Perry, "the most important function of the Court, and the judiciary generally, in the modern period" (p. 37). But what exactly is this function? Perry's answer: "The function of noninterpretive review in human rights cases is prophetic; it is to call the American people-actually the government, the representatives of the people-to provisional judgment" (pp. 98-99). The Supreme Court's function is to provide "moral leadership" and, by doing so, to initiate a dialectic between itself and the rest of the polity. Noninterpretive review, in short, "represents the institutionalization of prophecy" (p. 98).

The author's functionalism is rooted in what he regards as the unique feature of the American historical experience. We as a people are called to "prophecy" because of "the American people's religious understanding of themselves." As a political community we have believed ourselves a "chosen people"-" an American Israel" - charged with the fulfillment - in the United States and around the world- of a "binding vision" rooted in God's will and in higher law. Today this "religious" understanding of ourselves takes the more secular form of a commitment

* One of these arguments is that because the people have ordained the Constitution, setting up the Supreme Court as its final interpreter, they have imposed judicial supremacy upon themselves. Another is the argument that judicial review is compatible with democracy when it upholds democratic values. The reverse side of these arguments, which also meets the sharp blade of Perry's scythe, stresses the antimajoritarian side of American government and accordingly defends the Supreme Court as one political actor among many in a system characterized more by interest group pluralism than by majoritarian democracy. 
"to the notion of moral evolution." We as a people are still struggling to see the truth and distinguish right from wrong and to submit ourselves to "moral reevaluation" for the sake of continued "moral development" (pp. 100-101).

The Supreme Court, naturally, is the institution best qualified to perform the function of "moral reevaluation" in the American political system. The justices are insulated from the pressures, biases, and daily cares that limit and buffet the lives of legislators and executive officials. Since they don't have to worry about the next election, they can afford to be moral philosophers. A reflective institution, the Supreme Court is uniquely capable of submitting "challenged governmental action to a moral critique," of "assum[ing] a prophetic stance," of "opposing itself to established conventions," and of reminding us of our best selves ( $p$. 112).

This function is most crucial with respect to human rights. For in this area, Perry argues, where moral issues abound, "right answers" are possible. Indeed, the legitimacy of judicial policymaking depends on the capacity of judges to develop right answers in human rights cases. Little wonder, then, that the author attacks the moral and ethical skepticism pervading so much of modern constitutional theory, particularly processoriented theory. But he proceeds to draw a "critical distinction between a right answer and any particular rationalization that may be offered in its support" (p. 110), allowing for the rejection of claims to the inherent truth of any particular belief system. The right answer instead will often represent "a point at which a variety of philosophical and religious systems of moral thought and belief converge" (p. 109). The right answer to human rights issues, we learn, is not necessarily "orthodoxy" but rather "orthopraxis," namely, right action or "the correctness of a given answer."

But again, we might ask, where are these right answers to be found? A number of Supreme Court commentators have advised the Court to consult tradition, conventional morality, consensual values, or enlightened notions of justice as sources of judicial policymaking. Perry rejects all as adequate guides to constitutional decision. Rather, the judges should consult their "own moral vision," their "own values," and, by clear implication from all that Perry says, the insights of contemporary moral philosophy.

Yet noninterpretive review is ultimately coercive and at odds with majoritarian democracy. The Supreme Court, as Perry makes clear, is "an electorally unaccountable institution." Even so, Perry believes that constitutional policymaking is not necessarily in contravention of the principle of electorally accountable policymaking. The rest of his argument tries to show that the Supreme Court is-and should be-"subject to significant political control" (p. 126). The Court makes mistakes and serious ones, as in the Dred Scott case, and when it does, the political branches ought to be able to correct the mistake through the majoritarian political process. Perry finds this remedy-a remedy opposed as unconstitutional by a number of Supreme Court commentators-in Congress's power under Article III to limit or abolish the appellate jurisdiction of the federal courts. The amendatory process, he concludes, is 
an ineffective political check on the Court because of its requirement of a supermajority.

\section{B. THE HERESY OF JUDICIAL SUPREMACY}

What Michael Perry applauds John Agresto deplores. The Supreme Court and Constitutional Democracy is a critique of judicial activism. Over the decades, charges Agresto, we have moved from a regime of judicial review to a regime of judicial supremacy. The result is not Perry's "orthopraxis" but a "new orthodoxy," namely, a view of the Supreme Court as a physician charged with curing the ills of a sick body politic, manifesting distrust of democracy and disregard for history. The thesis of the book is simply stated: "[C]onstitutional interpretation is not and was never intended to be solely within the province of the Court, for constitutional government implies that the ultimate interpreter of our fundamental law is not an autonomous judiciary but the interactive understanding of the people, their representatives, and their judges together" (p. 10).

In Agresto's view, the Supreme Court has drifted away from its moorings in original constitutional theory. Much of the book is devoted to mapping the course of this drift and rehearsing the historical arguments over the validity of the course. Marbury v. Madison (1803), the Lincoln-Douglas debates, and the conflict between President Jackson and Chief Justice Marshall are recalled to illuminate the problem of judicial review in America today. Across the sweep of time, concludes the author, we have moved from Hamilton's "least dangerous branch" to a mighty and imperial judiciary.

This interpretation of the American experience with judicial review rests ultimately on what Agresto regards as the meaning of the Constitution. For Perry as for Chief Justice John Marshall the Constitution is the supreme law of the land, enforceable by the judiciary. For Agresto, on the other hand, the Constitution is a "framework for limited government." That is, it sets up "a constitutional democracy of separated powers, checked and balanced" by various institutional devices and auxiliary precautions. On this view "judicial review becomes part of an interlocking totality of governance" (p. 71). In short, the Constitution is a check on all branches of government, including the judiciary. Judicial review is one of those checks, a key check for sure-the one that "completes the circle of checks and balances"-but not the foremost check. No one branch of government is autonomous. All three are truly coordinate. The Constitution, then, contemplates not the finality of judicial power but a "real partnership" among the three branches, an "overall harmony which only the interweaving of dissonant parts can produce" (p. 39).

The problem with the Supreme Court today, in the author's estimation, is that it has become a ruler of the polity rather than an interpreter of the Constitution. Whereas Perry praises the policymaking role of the Court, Agresto condemns it, especially when it takes the form, as he thinks it has in the last thirty years, of "affirmative" rather than "negative" judicial review: that is, when the Supreme Court acts not merely to check legislative action but rather to reshape society by making new social policy. In this respect the Supreme Court does not function, as Perry argues, as a creator of constitutional dialogue or as a generator of the so- 
ber second thought in the larger political community. More often than not it has stopped the conversation, concluded the argument, and foreclosed any policy other than the one it has mandated. In short, as Agresto entitles one of his chapters, "from this Court there is no appeal."

Agresto never questions the legitimacy of judicial review. He is one with Perry in believing that interpretive review probably has the sanction of original history and that the Court plays a critical role in the human rights field, although they would surely feud over the legitimacy of some forms of noninterpretive review. Indeed, a constitutional theory faithful to the memory of the Founding Fathers is one "that recognizes and encourages the exercise of judicial review" (p. 102). But, he insists, "it must also be a position that understands the tenuous connection between judicial review and republican government" (p. 102). So we need to find a middle path by defending judicial review within a system of mutual checks and balances, a path that promotes the healthy tensions within the system, ensuring the preservation of judicial review, constitutionalism, and democracy.

How, then, are we to restore equilibrium to American government? Agresto, like Perry, rejects the amendatory process as a workable check upon a Supreme Court that decides wrongly. For Perry, a supermajority is too high a hurdle to overcome. For Agresto, on the other hand, resort to amendment is an admission that the Constitution has failed "to restrict the autonomous exercise of political power" (p. 108). Requiring a constitutional amendment to reverse the Court, says Agresto, is like requiring an amendment to reverse a presidential directive. The impeachment, appointment, and consent strategies are also in the author's view ineffective constraints. (Perry would agree, once again because these devices require supermajorities.) We saw that Perry's democratic resolution to the problem of "judicial overextension" was Congress's control over the Court's appellate jurisdiction. This, too, Agresto rejects as politically ineffective, and he marshals a lot of history to sustain his view.

What is needed is something far less than the major surgery implicit in all these "solutions." The real solution is for the three branches to begin acting as if they were coordinate with one another. Congress especially, in Agresto's view, needs to reassert its authority to interpret the Constitution. Too often senators and congressmen have abdicated their authority to the Court. If the Court has decided wrongly Congress should, in Agresto's view, force a reconsideration of the constitutional issue. Just as the Supreme Court should encourage Congress to engage in sober second thinking, so too should Congress engage the Court in such thinking. Agresto cites child labor legislation in the thirties and civil rights legislation in the sixties as prominent examples of Congress doing just that in response to regressive judicial policies in both areas. Another example, perhaps, that Agresto might have used is the Hyde Amendment. Is that Amendment Congress's reflective response to Roe v. Wade (1973)? Was Congress sending a message to the Supreme Court concerning its own thoughtful view of the relative constitutional merits of abortion and childbirth? Finally, was Harris v. McRae (1980) the Supreme Court's studied response to Congress's constitutional view or to the 
Court's own earlier view in the light of the congressional reaction? In any case, Agresto's threshold for "checking" the Supreme Court is lower than Perry's. Congress can more easily check the Supreme Court through Article I than through Article III.

\section{c. THE CONSTITUTION AS A WAY OF LIFE}

Sotirios Barber, if brought into conversation with Perry and Agresto, would charge them both with asking the wrong questions about constitutionalism. The issue is not, in his view, the legitimacy of judicial review, how judges should interpret the Constitution, or even the consistency between judicial review and democratic theory. He makes a sharp distinction, as does Agresto, between the Constitution and the Supreme Court's interpretation of it. But he clearly rejects the notion, supported by Agresto, that "today's constitutionalism is a constitutionalism of separated powers" in any Madisonian interest-based sense. By the same token, he is one with Perry in believing that our Constitution summons us to moral growth as a society and as individuals. Yet Barber totally rejects the noninterpretivism approved of by Perry. "[D]ifficult constitutional questions should [not] be resolved solely with an eye to what seems necessary to achieve the good society" (pp. 11-12).

Yet the good society is the key to Barber's understanding of the Constitution. The Constitution is, in his view, "an instrument of justice" and "a framework for the pursuit of happiness." It contains our deepest "aspirations" as a people. Its provisions, when read carefully and against the broad purposes of the Preamble, project a vision of an ideal society. If we would really wish to know the "ways of the Constitution" and aspire to observe them, fighting our natural tendency to go against the Constitution, we would realize an American "version of public happiness" (p. 75). In taking the supremacy of the Constitution as law seriously, we must "believe that the ways of the Constitution constitute our best conception of the good society" (p. 59). And if we really think about what the document means instead of allowing ourselves to be deflectedor misled-by judicial and scholarly interpretations of it, we will even find that the classic antagonisms of our constitutional law-for example, general welfare versus personal value, right versus right, and constitutionalism versus democracy - soon disappear. The Constitution, very simply, has one meaning. The bundle of compromises once thought to have been stitched together to form the Constitution is thus reduced to a magnificent coherence in the sublime glow of aspirational constitutionalism.

On first impression this basically teleological approach to the Constitution would seem to lay the groundwork for an excessively activist regime of judicial policymaking. Yet Barber's Constitution is more limited than Perry's. For one thing, Barber labors to ground his understanding of the Constitution in the document itself. He is not enraptured, as are so many Supreme Court commentators these days, by the play of judicial imagination under the open-ended phrases of the Constitution. He plows deeply into the text, exposing the true meaning of its multiple provisions: The Bill of Rights is a celebration, he finds, of the kind of people we would wish to be, namely rational persons capable of thinking and choosing for ourselves; the powers of the national government define lim- 
ited ends but must be used, affirmatively, to create the conditions for the most effective exercise of rationality, thought, and choice; finally, the Constitution's institutional provisions-from separation of powers to checks and balances-also serve to reinforce the rationality and collegiality of American politics. "[T]he constitutional process," Barber says, "is a continually self-critical quest to sharpen our vision of an ideal state of affairs and, to the extent that constitutional language and tradition permit, improve our conceptions of constitutional provisions accordingly" (p. 60).

Barber's Constitution turns out to be more limited than Perry's-and Agresto's-in still other ways. Perry devotes an entire chapter of Human Rights to a defense of institutional reform litigation in the federal courts; but Barber, like Agresto, questions the validity of the judiciary's equity power when used "to fashion highly detailed, long-range remedies covering many activities within a given system" (p. 202). Such use of judicial power is as much an invasion of legislative power, in his view, as the legislative veto is an invasion of executive power. In addition, and after examining the ends of national power, Barber concludes that Congress's resort to the commerce clause as a "pretext" for achieving an objective other than the health of the national economy is probably unconstitutional. (He doubts the validity of all such pretextual uses of federal power.) Also challenged on constitutional grounds are accepted doctrines and conventions such as the "inherent power" of the national government over foreign affairs, the judicial monopoly of constitutional review, and the legislative practice that allows interest group conflict rather than rational argument to dictate the choice of socioeconomic policy. A final illustration of Barber's more limited Constitution is this pregnant comment: "I do not see anything in the historical claims of this nation, in its aspirations, in the nature of reason, in constitutional language, or in our ordinary views of what is admirable that would yield true constitutional status to a right to abortion per se" (p. 147).

The abortion issue is a good illustration of how Barber sees the Constitution working itself out in our daily lives and in government. He just noted that abortion as such is not a right. Yet the legitimacy of any antiabortion policy would have to be defended or opposed in the light of priorities inferable from the Constitution's "arrangement of rights and powers." What is favored by the Constitution, Barber finds, is a secular society composed of persons with open and inquiring minds. The validity of an abortion ban, then, depends on the quality of the argument supporting it. Religious reasons or even "religiously motivated bans" on abortion are clearly unconstitutional. He grants, however, that good secular arguments may be available to support an antiabortion policy, and he discusses some of them. But the best minds among us-open minds in search of truth-must be convinced that such arguments are more than "pretextual." We even find that "new reasons against abortion would have to come from new sources in order to have a chance of appearing even arguably constitutional to those who favor abortion" (pp. 139-140). Barber's Constitution, it seems, was made for the strictly rational society. 
In many ways, Barber's final chapter on "constitutional institutions" is the most interesting. It also presents the sharpest contrast to Perry's defense of noninterpretive judicial review. Agresto, on the other hand, would utter a loud "Amen" to much of what is said here even though he differs from Barber in his basic conception of the way constitutionalism is implied in separation of powers and checks and balances. To begin with, according to Barber, the Supreme Court is not primus inter pares among the branches of government. A constitution with "one meaning does not imply [as Perry's functional theory does] one interpreter" (p. 197). Indeed, and again squarely contrary to Perry's functionalism, the one interpreter thesis "does not express a special concern for maintaining the Constitution as law" (p. 197). The reason: The Supreme Court may be wrong; it often changes its mind; and the Constitution cannot have more than one meaning. For this reason, all branches of the government are equally responsible for upholding the Constitution. They are also equally responsible for instructing one another in the Constitution's ways. No branch of government may "be asked to cooperate with unconstitutional acts, including unconstitutional judicial acts" (p. 199). All units of government and indeed all citizens, if they would wish to live by the Constitution, must reaffirm it at all times-consciously, consistently, and forthrightly.

\section{An Assessment}

Michael Perry's Human Rights invites particular attention in this conclusion because of its sturdy defense of the Supreme Court's prophetic role in American politics. Not unsurprisingly, the book has met with relentless criticism, much of it based on interpretive constitutional theory or variants of noninterpretivism that find some sanction in original history. My preference is to avoid the rehashing of this particular debate and to dwell, instead, on the two assertions that form the backbone of the argument on behalf of prophecy and, for reasons of economy, to weave into this discussion certain related threads from Barber and Agresto.

The first assertion is that there are right answers in constitutional law. Perry remarks that if judicial answers to human rights issues are not "right" then the argument for noninterpretive review collapses. One could quarrel with this statement, as Barber and Agresto impliedly do, but it is more important here to single out for attention Perry's related attack on the moral skepticism pervading so much of American constitutional jurisprudence. He posits the reality of moral knowledge and the capacity of the judiciary objectively to discover it. Perry's project is commendable, for any post-Holocaust constitution which places the dignity of the human person at the center of its value system should reject the subjectivism or emotivism that has come to be associated with a morality of process.

The question remains: What is a right answer? Although we never learn what a right answer would look like in hard cases arising under the First and Fourteenth Amendments*, we are informed that such an an-

* The rights of persons in closed institutions, which the author takes up in his concluding chapter, are not the hard cases we have in mind. Our principal concern is with a government of free men and women, not the government of prisons or mental hospitals. 
swer would probably not correspond to any particular value system. Instead, Perry argues, a right answer is likely to represent the point where a variety of philosophical and religious systems converge. But how would that point of convergence differ from the broad moral consensus currently informing American public law, a consensus, incidentally, that Perry rejects as a valid basis of judicial activism? Here the argument is fuzzy. The author defends substantive values in constitutional law. But the right answer thesis, as Perry pursues it, questions the "rightness" of substantive values that most Americans would wish to live by. Perry's average judge, like Barber's aspirational jurisprudence, is constantly engaged in questioning established values. In the end, both projects stripor so it seems-the constitutional polity of all meaningful substantive values.

Perry's project would be easier to evaluate if one could clearly identify the epistemology at the basis of his moral judicialism. Ronald Dworkin (Taking Rights Seriously) and Alan Gewirth (Reason and Morality) ground their jurisprudence in Kantian ethical rationalism, the predominant strain today of nonutilitarian moral philosophy. Perry's moral reasoning - to the extent that we can identify its content from Human Rights and his other writings - seems to be based upon this same strain of ethical thought, a strain of thought steeped in old canons of liberal psychology and political liberalism, positions we are not sure Perry would wish to maintain. There is a strange ambivalence in Perry's total work product. On the one hand, he envisions a constitutional polity marked by moral progress and evolution. Yet the Supreme Court in its prophetic role will not allow the polity to enact laws calculated to lead men to-or even to help them achieve-moral virtue or perfection. Of what then does moral progress consist? The ethical rationalist who would posit an objective order of morality based on universalist norms seems unable to provide an answer, at least not an answer that would identify right answers in substantive terms. That leaves what Perry ultimately-or so, again, it seems-gives us: a public square denuded of all authoritative values pertaining to the nature of the good life.

One suspects, at this stage, that "right answer" jurisprudence is itself in need of rethinking. My own emerging view is that we are mistaken in equating "objectivity" in constitutional reasoning with the moral rationality of contemporary ethical theory. That rationality, as Stanley Hauerwas and Alasdair MacIntyre have pointed out, renders alienation of the self a central moral virtue: First, it abstracts persons from the meaningful contexts within which they live their lives and define themselves; second, it reduces ethics to the making of a choice, and on the basis of disembodied reason, between alternative courses of action. In their powerful critiques of standard moral analysis, ${ }^{*}$ Hauerwas and MacIntyre

* See Alasdair MacIntyre, After Virtue (University of Notre Dame Press, 1981); Stanley Hauerwas, A Community of Character (University of Notre Dame Press, 1981), and Truthfulness and Tragedy (University of Notre Dame Press, 1977); also Alasdair MacIntyre and Stanley Hauerwas, editors, Revisions. Changing Perspectives in Moral Philosophy (University of Notre Dame Press, 1983). 
propose not a morality limited to decision theory-that is, how does a person get out of this particular dilemma?-but rather one based on character and narrative. Seeking to avoid the damage to personality and character that too often results from an overemphasis on rights-or on the right answer-they propose an account of ethical reasoning rooted in the identity, personality, and life-story of an individual, thereby putting the human personality back into ethical reasoning without sliding into a wholly subjective morality.

The Hauerwas-MacIntyre approach to ethical reasoning has important implications for constitutional analysis. With respect to abortion, for example, a state might wish to encourage a woman to consider the significance of pregnancy and childbirth and to reflect on what these events mean in the life of the community-or communities-to which she belongs. The Supreme Court, however, seems determined to strike down any and every law designed to enhance the quality of moral rationality or to encourage the exercise of moral choice within a framework of familial, communal, or social relationships. The Supreme Court's neglect of character and narrative is understandable given its image of the person as an alienated self, isolated and autonomous. In a world peopled by such individuals what else besides a certain kind of cold rationality is to shape moral choice? The Court would be truer to the human condition if it allowed friendship and fraternity to play itself out before seeking to "impose" right answers on anybody.In truth, the constitutional value of equal respect and concern for all persons would seem to demand nothing less than a sensitive narrative assessment of real life situations.

Barber's aspirational jurisprudence is also marked by a rationality ultimately destructive of friendship, sociality, and other personal bondings. His constitution is ordained not for communities of interest but, as noted earlier, for the society-the debating society writ large-in which everything but a certain kind of cold rationality is questioned. There is of course much to admire in Barber's vision of the model citizen-the constantly self-critical and questioning member of society. But that citizen often looks like the typical uprooted individual of our postindustrial civilization-that is, the well-educated, culturally homogeneous person on the move as well as on the make and, as my colleague Robert Rodes has put it, "better able to derive satisfaction from organizational and technical accomplishments than from personal relations" (Law and Liberation, forthcoming). Barber's rational polity comes dangerously close to relegating communities of belief and feeling to the periphery of society. One suspects that the policy of Yoder $v$. Wisconsin (1972) - a landmark religious free exercise case releasing Amish parents from the duty to obey compulsory school attendance laws - would be suspect in Barber's constitutional polity. One might have thought that constitutional law is at its best-actually at its aspirational best-when it defends, nurtures, and reinforces traditional communities of belief, sentiment, and love. Most people experience the fullness of life within such communities, finding in that fullness the truth of their being.

One of the most disconcerting features of Barber's rational polity is its reluctance to give legal effect to any social agenda motivated by reli- 
gious convictions. We might return to the abortion issue to illustrate the consequences of this view. Barber notes that antiabortion groups in American society are motivated by religious feeling. That view is mistaken, but let us assume that it is true. It turns out that these groups have nothing more of significance to contribute to the abortion debate. "New reasons against abortion," he tells us, "would have to come from new sources in order to have a chance of appearing even arguably constitutional to those who favor abortion" (pp. 139-40). Apart from the argumentum ad hominem fallacy that any such view entails, it pushes religious groups onto the margins of society. They no longer meet Barber's definition of the model citizen. Their arguments may be rooted in an illustrious tradition of Western thought, but that accounts for nothing if that thought is tainted by even a trace of religious sentiment. "Whatever all this is," notes Professor Rodes, "it is obviously not respect," for "it tends . . . to demean every citizen who takes religious questions seriously" (Law and Liberation). Overlooked in Barber's rational polity are the numerous ways in which law could be used to help-even encouragereligious persons to live out more easily their vision of the good life and without degrading contrary visions of the good. It may be true, as Barber suggests, that "the Constitution cannot accommodate all views of happiness and the good society" (p. 75), but it can accommodate the views of most of us.

And yet, for all that, Barber's constitutionalism is appealing. It holds us all to a high standard of citizenship, emphasizing the importance of dialogue and communication as the most effective route to community. Barber calls us to account as much for our lack of constitutional consciousness as for the failure of constitutional law to abide by the specified limits of the Constitution. The Constitution, for him, addresses us in the language of obligations as well as rights, placing upon Congress and state legislatures an affirmative duty to enact laws and adopt policies designed to eliminate social inequities that degrade people, inhibiting the flowering of personality and the performance of duty. Barber's discussion of equal protection jurisprudence is equally cogent: He ignores the nonsensical jargon of "degrees of scrutiny" analysis and speaks directly of core values that should dictate all of our equal protection jurisprudence.

We conclude this essay by returning to Perry's Human Rights and the second major assertion on which the argument on behalf of noninterpretivism is made. The assertion is that the Supreme Court is uniquely capable, institutionally, of making right decisions in human rights issues. We shall not tarry long on this final consideration. Suffice to say that the assertion of the Court's unique institutional capability is just that - an assertion, and one badly in need of reassessment. The thesis that insularity from politics produces better decisions or superior wisdom on the part of the judiciary is almost wholly without empirical support. In fact, the evidence may point to the contrary. In a recent and seminal article, Neil K. Komesar has listed the numerous shortcomings of the view that legislatures are less capable than courts of engaging in principled inquiry. *

* See Neil K. Komesar, "Taking Institutions Seriously: Introduction to a 
We could also note that judges are not moral philosophers, nor should we expect them to be. They have not been trained in moral philosophy and are not temperamentally disposed to "do" moral philosophy. Even if we could put moral philosophers on the bench many of us would be leery of doing so out of fear of the kind of moral philosophy they would represent. The day we begin classifying judges as "Rawlsian," "Ungerian," or even "MacIntyrian" is the day constitutional law will dissolve as a practical art. Our stumbling constitutional polity is not prepared to accept judicial prophets-any more than it is prepared to accept Dworkin's Hercules. Our need is for judges more modest in aspiration. We should prefer men and women of character who have a narrative understanding of our national polity. We should, in brief, prefer judges steeped in the existential forces of life whose wisdom is the deposit of experience and reflection.

One of the alleged advantages of a Supreme Court in a prophetic role is its capacity as an educator or as a stimulator of dialogue, in and out of Congress, about human rights and other constitutional issues. Agresto's twist on separation of powers is a cogent response to this argument. $\mathrm{He}$ like Perry sees the Supreme Court as an important articulator of principle, uniquely capable of reminding all of us of our collective duty to bind ourselves to the Constitution. Agresto and Barber, however, are one in underscoring the incompatibility between the design of our constitutional institutions and the finality of judicial policymaking. It is precisely this finality-bordering, as Agresto notes, on absolute finality-of judicial power that strangles the dialectical relationship among our constitutional institutions. The judiciary plays more of a dialectical role, really, in those constitutional democracies whose high courts are permitted to issue advisory opinions.

The reference to other constitutional democracies incidentally reminds us of certain admonitory or "dialectical" functions of West Germany's Federal Constitutional Court. Despite the Constitutional Court's clear mandate to nullify statutes incompatible with the Basic Law, it frequently refrains from doing so. Instead, the Court often stays its hand while admonishing the legislature that a statute will, at some future time, be declared unconstitutional unless the legislature amends or repeals it. In other instances, the Court declares a statute unconstitutional but not invalid or, after articulating its constitutional views on a particular issue, appeals to parliament for a change more consistent with the relevant constitutional principle; in still other instances, the Court temporarily "enacts" its own changes in the law until parliament has had a chance to respond.

These are all examples of where the Federal Constitutional Court clarifies a constitutional principle but leaves the application of the principle to another unit of government. One can of course cite comparable

Strategy for Constitutional Analysis," The University of Chicago Law Review, 51 (Spring 1984), 366-446. See also Gerald N. Rosenberg, "The Courts, Congress and Civil Rights: Comparing Institutional Capabilities" (Paper delivered at 1983 Annual Meeting of the American Political Science Association, September $1-4,1983$ ). 
practices in American constitutional law but the German approach locks judiciary and parliament into a tighter dialectical embrace, the kind of embrace that Agresto has in mind in Constitutional Democracy. The German Court has also found ways to act as educator without hurling mandates at the political branches of government. Barber would glow with approval over the German Court's disposition of the Basic East-West Treaty Case (1973). There the Court upheld the constitutionality of the Basic Treaty between East and West Germany, which appeared to approve of the concept of two German states, but went on to lecture German leaders on their responsibility of achieving, ultimately, the basic constitutional goal of German reunification.

These parenthetical remarks about the Federal Constitutional Court furnish the occasion, finally, for returning, ever so briefly, to the problem of moral truth and objectivity in constitutional law. Dworkin, Perry, and other commentators are appealing to moral philosophy for help in getting beyond subjectivity in constitutional law. We would recommend comparative constitutional law as a superior initial source of wisdom in the resolution of human rights issues in our day. Several constitutional courts in the advanced democracies of Western Europe and elsewhere have been grappling with the full range of human rights issues marked by so much constitutional commentary in the United States. If this jurisprudence, comparable to our own, is studied closely, we may find a common core of agreement on certain constitutional values pertaining to the relationship between persons and the legal order, a common core of wisdom derived from hard jurisprudential labor to reconcile the demands of liberty with claims based on equality and community. Can we really ignore the accumulated wisdom of common core jurisprudence? Blending the insights and reflections of many peoples, the common core would surely represent, if not perfect objectivity, certainly a kind of transsubjectivity that would avoid the extremes of emotivism and absolutism. It is just possible that common core jurisprudence would provide us-even us Americans-with the "right" answer to a lot of constitutional issues. 